\title{
Popielec Urbana Szostowicza - nieznany utwór nieznanego autora
}

Joanna Napiórkowska 


\section{Joanna Napiórkowska}

\section{Popielec Urbana Szostowicza - nieznany utwór nieznanego autora}

Tnteresıjąc się przeszłością, rzadko kiedy zdajenny sobie sprawę, iż jedıym z praw, którymi Irządzi się historia, jest... zapominanie. Często się zdarza, że lıdzie cenieni przez swoich współczesnych wraz z upływem czasu, z rozmaitych (niè zawsze zrozumiałych) powodów odchodzą w niepamięć. Taki los spotkał między innymi Urbana Szostowicza, członka Zakonu Kleryków Regularnych Ubogich Matki Bożej Szkól Pobożnych.

Michał Szostowicz przyszedł na świat 26 września 1745 lub 1746 roku1', w województwie krakowskim. Niestety, źródła, które dotrwały do naszych czasów, nie podają jego pochodzenia (nic jest również notowany w herbarzach), trudno też o bardziej szczegółowe wiadomości dotyczące jego życia (warto paniętać, iż przeważąąca część zbiorów Archiwum Polskiej Prowincji Pijarów spłonęla w Powstaniu Warszawskim).

Najprawdopodobniej uczęszczał do elementarnych szkół pijarskich, a 17 października 1762 roku wstapił do zgromadzenia pijarów. Tam przybral imię zakonne Urban od św. Michata.

Po odbyciu dwuletniego nowicjatu postanowił w pełni zrealizować hasto Zakonu Pietas et Litterac („Pobożność i nauka”) — zgodne z myślą zalożyciela, św. Józefa Kalasancjusza, który na pierwszym miejscu stawiał wychowanie w duchu pobożności i wyksztalcenie dla samodzielnego utrzymania - i wstappil na drogę naukową. W latach 1764/65 studiował retorykę w Sączu, 1765/66i 1766/67 - filozofię w Międzyrzeczu Koreckim, a następnie, w roku szkolnym 1772/73 — teologię spekultatywną w warszawskim seminarium pijarskim.

\footnotetext{
${ }^{1}$ Bibliografia polska Karola Estrcichera (t. 30. Kraków 1934, s. v.) podaje rok 1745, natomiast Szymona Biclskic-

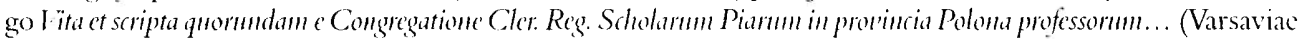
1812) $-\operatorname{rok} 1746$
} 
Ukończywszy szkoły, Szostowicz zostal nauczycielem matematyki, filozofii i wymowy (co pozwala w nim dostrzec nie tylko humanistę, w dzisiejszym tego słowa znaczeniu, ale i sprawny umysł analityczny). Uczyl między innymi w kolegium międzyrzeckim i w Radomiu, a następnie w warszawskim Collegium Nobilium, gdzie sprawował również funkcję wiceprefekta $(1777 / 78)$.

Ojciec Urban okazał się zdolnym pedagogiem i dobrym nauczycielem, prawdopodobnie lubianym i szanowanym przez większość uczniów oraz cenionym przez ich rodziców - pozual go między innymi Mikołaj Malachowski, wojewoda sieradzki.

Słabe zdrowie i długotrwała cloroba (1779-1782) sprawily, iz Szostowicz nie był w stanie wywiązywać się ze swoich obowiązków w Collegium Nobilium — w 1783 roku, za zgodą przełożonych, osiadł na dworze Małachowskich, gdzie zajął się wychowaniem Jana Nepomucena, najstarszego syna Mikolaja.

Zanim choroba odebrała mu sily i miejsce w Colleginm Nobilium, ojciec Urban żył aktywnie, prowadzil dosyć bogate życie towarzyskie. Jak wynika z utworów okolicznościowych jego autorstwa, na pewno był związany między innymi z Joanną i Mikołajem Piaskowskimi, podkomorstwem krzemienieckim, znał dobrze Stanisława Bielińskiego, starostę garwolińskiego, prawdopodobnie bywał w salonach Józefy Aleksandry Ogińskiej, gdzie spotykala się młodzież i ludzie związani z kulturą, musiał również znać generała-brygadiera wojsk francuskich, zarazem literata, Wojciecha Jakubowskiego i calą śmietankę warszawskiego towarzystwa.

Równiez po wyjeździe z Warszawy czymie uczestniczył w życiu, realizują̨c się jako duszpasterz na probostwach: w Wojniczu (1786), Chęcinach (1787-1790) i Końskich (od 1791).

Ważnym okresem w życiu Szostowicza byly lata 1774-1777. Wspólpracował wówczas z "Zabawami Przyjemnymi i Pożytecznynı”, na których łamach opublikował dwadzieścia trzy wiersze (są to przede wszystkim utwory okolicznościowe i przekłady z francuskiego). Prawdopodobnie wlaśnie od tego czasu należy liczyć jego znajomość (czy nawet przyjaźń) z wielkimi literatami Oświecenia.

Ojciec Urban Sch. P. zajmowal się nie tylko nauczanienı i „wiązaną mową” - pracował również jako edytor. W 1778 roku wydal Stanistan'a Konarskiego Scholarum Piarum uniersze I'szystkie z taciniskich na polskic przetożone (które w większości sam thumaczyl), a cztery lata później - Stanistau'a Heraklego Lubonirskiego, marszatka niegdy's u'ilkiego koronnego, uiersze zebrane i przedrukon'ane. Warto zaznaczyć, że w obu tomach zamieścił wiersze dedykacyjne swojego autorstwa? ${ }^{2}$.

U schyłku życia (zmarl 19 grudnia 1792 roku) Szostowicz napisał prawdopodobnie kilka pieśni nabożnych, jednak dostępne dziś źródla potwierdzają tylko jedną, Popielec, która zachęcila mnie do napisania niniejszego artykulu.

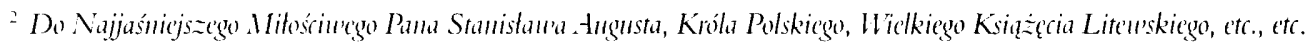

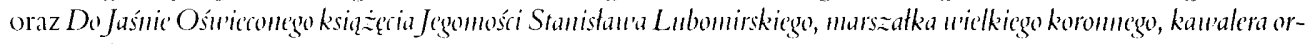
derón polskich. 
Oryginahna twórczość ojca Urbana od św. Michata to przede wszystkim literatura okolicznościowa, będąca świadectwem czynnego uczestnictwa w publicznym i towarzyskim życiu stolicy. Pojawiają siç tu utwory zainspirowane sytuacjani typowo towarzyskimi, jak imieniny czy interesıjąca dyskusja, a także wiersze związane z życiem szkolnym pijarskiego Collegium Nobilium? ${ }^{3}$.

Należy tutaj podkreślić, że choć utwory te z calą pewnością należą do twórczości pochwalnej, to daleko im jednak do panegiryzmu (krytykowanego zresztą i odrzucanego zarówno przez oświeceniowych poetów i teoretyków literatury, jak i nauczanie pijarów). Nie koncentrują się wylącznie na osobie adresata, zawierają̧ również refleksje moralne czy patriotyczne. Jednostkowe zdarzenie ukazywane jest na szerokim tle uwarunkowań społecznych i zastanej rzeczywistości - wiersze te są doskonatą ilustracją spoleczno-politycznych przekonań Szostowicza, a także jego duchowego zaangażowania w aktualne wydarzenia i bieżące sprawy ojczyzny.

Czytając poezje ojca Urbana szybko można się zorientować, iż byl on wyrazicielem idealów i poglądów dominujących w kręgu reformatorów życia kulturalnego i społecznego, otaczającym Stanislawa Augusta. I użo miejsca poświęcil kwestii szkolnictwa, podkreślając przewodnią rolę nowoczesnego ksztatcenia w procesie odbudowy „nadbutwiatej nawy”, jaką stała się Polska, osłabiona wewnętrznymi sporami i rozrywana przez sąsiednie państwa. Zaznaczał również inspiracyjne i mobilizujące do wytężonej pracy działania króla, który robi wszystko, co w jego (ograniczonej) nocy, aby wydobyć kraj z upadku. Stawiąc cnoty, które mają być wzorem postępowania dla „młodzi” czy „ojców i matek”, Urban Szostowicz wytyczyl ścieżkę, którą winni pójść jego czytelnicy, bo, jak pisał w jednym ze swych wierszy:

\section{Wiek będzie lepszy, kiedy lepsi ludzie ${ }^{+}$.}

„Przemycając” w swych okolicznościowych utworach treści o szerszym wymiarze, będące wyrazem troski o ojczyznę i nièustannej wdzięczności królowi za zaangażowanie w sprawy oświaty (co prawdopodobnie wynikało z idei Szkół Pobożnych), Szostowicz nie zapominał o sprawach ducha: podstawach wiary chrześcijańskiej, religii i filozofii. Najlepszym tego przykładem jest właśnie (napisany parzyście rymowanym, stychicznym ośmiozgłoskowcem) Popielec, który ukazał się jako druk ulotny ${ }^{5}$ w Warszawie, w 1788 roku.

\footnotetext{
"Na lamach .Zabaw Przyjemnych i Pożytecznych" ukazaly siç miçedzy innymi: Bukiet ma d:icú imicnin Jaśnie

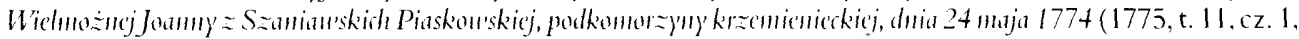

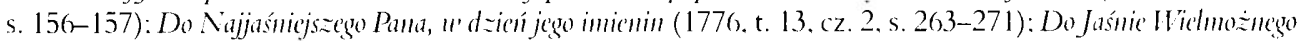

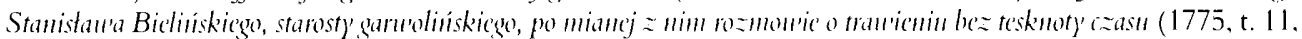

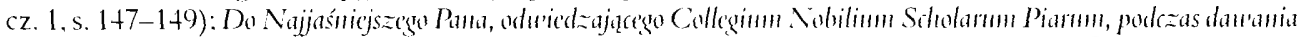

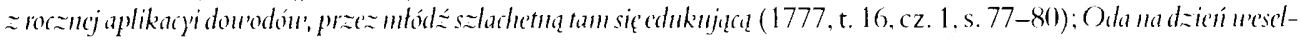

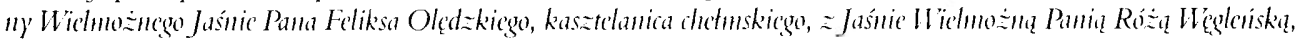
dhorażankiz cheturska $(1775$, t. 12. cz. 1, s. 55-59).

" Oda $I I I$ z tejze okolic znósi. ..Zabawy Przyjemunc i Pożytecznc" 1775, t. 12. cz. 1. s. 12-16: wszysthic cytaty pochodzą z przygotowanej przeze mnie edycji utworów okolicznościowych Urbana Szostowicza.

"Zachowany cgzemplarz Bibliotcki Narodowej w Warszawic: sygn. 13N 1291.864.
} 
Ten rajbardziej chyba osobisty i oryginalny wiersz Szostowicza doskonale wpisuje się w jego twórczość okolicznościową, gdzie pojedyncze wydarzenie staje się pretekstem do snucia rozważań o szerszym wymiarze. Posypanie glowy poświęconym popiołem dozwala poecie uważniej spojrzeć na zbyt szybkie przemijanie czasu, śmierć i sposoby pozbycia się lęku przed nią.

Porażony słowami kapłana, odprawiającego mszę w Środę Popielcową (inaczej: wstępną środę, rozpoczynającą katolicki Wielki Post), podmiot liryczny (który chętnie utożsamię z autorem wiersza...) z pehną ostrością zaczyna widzieć wlasną śmiertelność — nadciągającą zbyt szybko i nieodwracalnie. Przywołuje w pamięci młodośc, kiedy „Zdrów, wesół bujal po świecie", nie odczuwając biegnącego czasu. Jednak wraz z upływem lat coraz wyraźniej zdaje sobie sprawę z przemijania, które w ogromnym tempie prowadzi czlowieka z beztroskiego dzieciństwa w starość i śmierć:

O lata! Jak przemijacie!

Ptaków pędem przewyżzzacie!

Co tylko sily nastaty,

Jużci czlowiek i zgrzybialy;

Ledwo z pieluch uwalniaja,

Wkrótce całun zaściełają (w. 21-26).

Nieuchronność „pójścia w ziemię” budzi smutek i lęk, trapiący ludzkość od wieków. Przez lata mędrcy i filozofowie poszukiwali sposobu,

By pamięć na śmierć tak była,

Iżby czleka nie trapiła (w. 32-33).

Autor przedstawia propozycję Cycerona, który radzi pogodzić się ze świadomością śmierci, „Bo się śmiertelni rodzimy”. Ten sam los spotyka wszystkich ludzi, bez wyjątków i wyróżnień, niech więc „syn” - krok w krok za „ojcem” i „matką” — bez lęku przekroczy granicę pomiędzy życiem a śmiercią. Szostowicz jednak nie znajduje tu „folgi”:

Błaheż to jest pocieszenie,

Iść w gromadzie na stracenie;

Czyż przez to lizejsze me rany,

Że krwią drugich miecz był zlany? (w. 47-50)

Również Seneka nie daje pocieszenia znękanemu własną śmiertelnością człowiekowi. Jego wizja śmierci jako lekarza, kończącego wszelkie choroby i bolączki, zupełnie nie przemawia do poety:

Piękny-ż to lekarz Seneki,

Co trupa robi z kaleki! (w. 61-62) 
Nie znalazłszy ulgi („folgi”) u wielkich filozofów, Szostowicz wraca myślą do dzieciństwa i przypomina sobie słowa modlitwy, której uczyła go matka: „Wierzę w ciala zmartwychwstanie". Wreszcie kończą się poszukiwania:

Tak dłıgo w księgach szperałem,

A ja to dzieckiem umiatem (w. 73-74).

Poeta odnajduje lek na lęk przed śmiercią w religii clırześcijańskiej i życiı zgodnym z jej założeniami:

Tak jest: wierzę w zmartwychwstanie;

Niech mi śmierć w oczach już stanie -

Nie przelęknę się jej grotów,

Jeślim na sumnieniu gotów! (w. 79-82)

Śmierć nie jest już w stanie przerażać, jej rządy nie będą wieczne. Zgon ciała nie jest przecież zgonem nieśmiertelnej ludzkiej duszy, a i to nie jedyna perspektywa - wszak Biblia zapowiada „ciala zmartwychwstanie” i koniec panowania śmierci. Wezwane głosem anielskiej trąby „najdrobniejsze prochy” opuszczą groby i polączą się ze swym duchem, wskrzeszone Bożą mocą, a ich miejsce zajmie właśnie śmierć, „na wieki pogrzebiona”.

Szostowicz zdaje sobie sprawę, że na pewno znajdzie się jakiś sceptyk, który nie będzie chciał uwierzyć w zmartwychwstanie (.,Są dziś tacy, żal się Boże!”). Powołując się na autorytet Biblii, poeta wythumaczy niedowiarkowi, że — analogicznie - pierwsi ludzie zostali stworzeni właśnie z prochu, w który wszechmocny Bóg tchnąl życie:

Mógł człek być z ziemi stworzony,

Czemuż nie z ziemi wskrzeszony? (...)

Bóg tak chce i Bóg to może -

Wierz, nie wierz, wstaniesz, nicbożę (w. 113-114, 117-118).

Wszechmogący Pan jest gwarantem zmartwychwstania, znika lęk przed śmiercią i obawa, co się stanie „potem”. Czlowiek powinien tylko zadbać, aby ziemskim, cielesnym życiem zasłużył na Bożą laskę:

Myśl o tym, żebyś wskrzeszony

Na prawicy był stawiony! (w. 121-122)

Okazuje się, że tylko wiara w Boga i ,moc boską wiecznotrwałą" pozwala ludziom przestać lękać się śmierci, cieszyć się życiem doczesnym i nadzieją życia wiecznego.

Niemal całkowicie zapomniany Urban Michał Szostowicz nie doczekat sie jeszcze ani bardziej szczególowego biogramu (poza kilku- czy kilkunastozdaniowymi notkami), ani opracowanego wydania utworów. A był on niewątpliwie prawdziwym czlowiekiem Oświecenia, o otwartym sercu, w którym wiele micjsca zajmowaly sprawy Rzeczpospolitej, oraz 
umyśle, pozwalającym analitycznie spojrzeć zarówno na otaczającą, doczesną rzeczywistość, jak i na sprawy wiary i życia wiecznego. Choćby z tego powodu (nie wspominając już o przyjemności czytania...) warto calą twórczość ojca Urbana — nie tylko Popielec — „wydobyć z mola".

Podczas pracy nad modernizacją utworu pomocne okazały się dwa źródła: Zasady $w^{\prime} \gamma^{\prime} d a-$ u'ania tekstóll'staropolskich. Projekt, Wrocław 1955 (dla tekstów typu B) oraz zasady transkrypcji, przyjęte w planowanej edycji Dzieł Adama Stanisława Naruszewicza (do serii „Biblioteka Pisarzy Oświecenia"), opracowane przez Barbarę Wolską.

\footnotetext{
- Pozwolilam sobie posłużyć siç stowami Szostowicza wobec wydanycl przez siebie wierszy Lubomirskiego

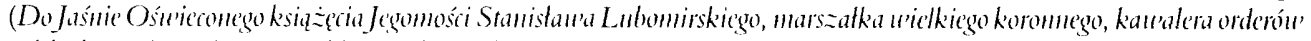
polskich. w: Stunistan'a Heraklego Lubomirskiego, marszatku nicgdy'ś w'iclkiego koromego, wiersze ze brane i przedrukou'ane. Warszawa 1782, w: 3).
} 


\section{Urban Szostowicz}

\section{Popielec}

Opr. Katarzyna Napiórkowska

Dziś rano, w dzień popielcowy,

Na włosy siwej mej głowy

Gdy kaptan sypal popioty,

Martwemu prawie na poły ${ }^{7}$

5 Rzekt nie slowa, lecz pioruny,

Przypominając do truny ${ }^{\star}$ :

„Pomnij, czlecze, ze twe plenic,

$\mathrm{Z}$ ziemi wzięte, pójdzie w ziemiç;

Unrzesz i już się nie wrócisz,

10 Proch jesteś, w proch się obrócisz!"'

Czy dawnoż człek się urodzil?

Czy dawno na paskach chodzil"'?

Gdy wspomnę na molode lata,

Tak ich bliska zda się data,

15 Żem co w samym życia kwiecie,

Zdrów, wesół bujal po świccie

Od rana aż do wieczora,

Przysiągłbym, że było wczora;

Rzekłbym, dwudziesty rok dnieje.

20 Kopę lat metryka pieje.

O lata! Jak przemijacie!

Ptaków pędem przewyższacie!

Co tylko sily nastały,

Jużci czlowiek i zgrzybialy;

25 Ledwo z pieluch uwalniaja,

Wkrótce całun zaściełają;

\footnotetext{
'Pod koniec lat osiendzicsiątych Szostowicz przebyl dlıgą i najprawdopodobnicj dosyé poważną chorobę̧. gdyz przyjacicle martwili siç o jego życic: ,W liścic Twoim przcplatasz mi smutek z radością, żem się doczytał o polepszeniu zdrowia Szostowicza. (...) Ale musi on być jeszcze słaby bardzo, kicdy w liścic Twoim jedncj przynajmuicj kenijki do mnic nic napisal. Wierz mi, że mi to tylc razy do glowy przychodzilo, żc możc juz on nie żyje. Bo przeszly list Twój do mnic o nim pisany miat cośniewyránnego" (list Franciszka Karpińskiego do pijara Michala Stadnickicgo, rektora kolegiów w (rórze, Lwowic i Warszawic, z 22 marca 1788 r., w: „Archiwum Litcrackic", t. 4: Korespondencja Franciszka Karpiniskicgo =lat 176.3-1825, do dr. przyg. T. Mikulski. koment. opr. R. Sobol. Wroclaw 1958).

* truna - trumuna.

" Nawiązanic do Billii. Rdz 3, 19: „W pocie oblicza twego będziesz pożywal chlıba, aż siç wrócisz do ziemic. z którcjeś wziçty; boś jest proch, i w proch siç obrócisz" (tl. J. Whijck).

${ }^{10}$ na paskach chodzil — uczyl siç chodzić (podnoszony przez opickunkę za pomoca gorsetu z dlugimi paskami z tyhi1).
} 
Dziś stolarz kolebkę knuje ",

Jutro na trunę hebluje.

Com nie rzekł, gdym w smutku brodził:

30) Szczęśliwszy, co się nie rodzil!! ${ }^{12}$

Jak tylko świat byl stworzony,

Tym smutkiem człek jest gryziony.

Tylu było mędrców dawnych.

Filozofów nader sławnych,

35 Co przez wszystkie wieki żyli -

Czyż folgi nie wymyślili,

By pamięć na śmierć tak była,

Iżby czleka nie trapita?

Jest sposób, mówią mi śmiele

40) Cycero ${ }^{13}$ i innych wiele:

„Trzeba myśleć (twierdzą oni),

Żésmy wszyscy w jednej toni,

Zostawać równic musimy,

Bo się śmiertelni rodzimy;

45 To ojca, matkę potkało,

Niech syn na śmierć idzie śmiało..."

Blaheż to jest pocieszenie,

Iść w gromadzie na stracenie;

Czyż przez to lżejsze me rany,

50 Ze krwią drugich miecz byl zlany?

W Senece ${ }^{1+}$ tez co czytany,

Pociechy niewiele many.

Chce w nas wmówić, że śmierć czleku

Nie jest straszna w kazdym wieku;

55 A gdy mu przyczyn nie staje,

Postać jej lekarza daje,

Iż wszystkie kończy choroby,

Choć ich najwięcej bylo by...

Wierzę, że chorób pozbawi,

$"$ knuje - od: knowac obrabiać drewno". "robić z nicgo jakiś przedniot.

12 Nawiązanic do Biblii. Koh 4, 3: „A miałem za szczęśliwego nad obudwur. który siç jeszcze nic narodzil, ani wiedzial zlego, które siç dzicje pod slońcem" (tl. J. Whijek).

${ }^{13}$ Cycero - Marcus Tullius Cicero (106-43 p.n.e.), najsłymicjszy mówca rzymski, w pismach filozoficznych (miçdzy imnymi: O graniadh dobrego i ztego, Rozpran'y akademickic, O maturze bogón') lączyl koncepcje różnych greckich szkól filozoficznych: cklektyk, w kwestii niéśnicrtelności duszy i lęku przed śmiercią skłanial się ku poglądom stoickim.

it Seneki - Lucius Annacus Seneca. Sencka Mlodszy (Filozof, ok. 3 p.n.e-65), syn Seneki Starszego (Retora); myśliciel i tragik rzymski, przedstawicicl późnego stoicyzmu; w dzichach (zwłaszcza Dialogi) przedstawil ideal mę̧dra, który nie ulega żadnym emocjom, zwłaszcza lçkowi przed cierpieniem i śmiercią. 
6) Ale wtenczas, gdy udawi.

Piçkny-ż to lekarz Seneki,

Co trupa robi z kaleki!

Gdy ja rękami obiema

Tam szukam folgi, gdzie nie ma,

65 Aż w tej mojej nudnej biedzie,

Przyszly na myśl slowa w Kred $=i e^{15}$,

Które matka mnic wrażala

I tylekroć powtarzała,

Gdym był jeszcze w dziecka stanie:

70) „Wierzę w ciala zmartwycluwstanie”!

Tą myślą bylem wzmocniony

Nad Seneki, Cycerony.

Tak długo w księgach szperałem,

A ja to dzieckiem umialem.

75 Dobrze-ż Augustyn "' powiada:

„Więcej mądrości posiada

Jedno dziecko chrzéścijańskie,

Niż filozofy pogańskie".

Tak jest: wierzę w zmartwychwstanie;

80) Niech mi śmieré w oczach już stanie -

Nie przelęknę się jej grotów,

Jeślim na sumnieniı gotów!

Rzeknę do niej: „Znam twe siły,

Wszystkich nas toczysz w mogily.

85 Rozumiesz, żeś juz wygrała,

Gdyś w ziemi nas zakopała?

Dom zgnity ciala zabicrasz,

Lecz wieczny duszy otwierasz,

I nad ciatem w tym zlym stanie

9) Krótkie twoje panowanic.

Przyjdzie czas (jak Pismo woła),

Gdy na głos trąby anioła

Musisz groby pootwierać,

Łupy swoje z nich wybierać

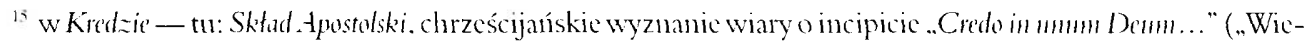
rzę w jednego Boga").

"Augustyn - Aurclius Augustinus (354-430), św., Ojcicc i Doktor Kościola, najwybitnicjszy przedstawiciel patrystyki lacińskicj. Stworzyl podwaliny filozofii clırześcijańskicj. przcjnując dzicdzictwo filozofii antyczncj. Podstawowym pojęciem ctyki Augustyna jest milość występująca razem z wolą. Wedlug niego czlowick może rozwinąé swoje możliwości poznaweze przez wiarę, a poprzez poznanic potwierdzić treść wiary (Credo ut intelligam; intelligo ut credum - ..Wierzę. aby poznać: poznaje, aby wicrzyć”). 
95 I wrócić je z twoich lochów

Aż do najdrobniejszych prochów.

Te zaś z swą duszą spojone,

Mocą Boga ożywione,

Wstaną na anielskie głosy,

100 Jak z martwego ziarna kłosy;

A w prózne juz nasze groby,

Twych zwycięstw niegdy ozdoby,

Będziesz tam sama wtrącona

I nla wieki pogrzebiona..."17

105 Rzeknie kto: „Jak to być może

(Są dziś tacy, żal się Boże!),

Zeby czlek, zgniły, spróchniały,

Znowu powstal żyw i caly?"

Ja też takiego niech spytam:

110 "Adama (co w Piśmie czytam) ${ }^{18}$

Jako z gliny ulepiono

I w momencie ozywiono?

Mógł czlek być z ziemi stworzony,

Czemuz nie z ziemi wskrzeszony?

115 Czyż moc boska wiecznotrwała

Z czasy zmniejszona zostala?

Bóg tak chce i Bóg to może -

Wierz, nie wierz, wstaniesz, niebożę.

Nie lam glowy, jak to będzie -

120 Bóg lacno wszystko odbędzie;

Myśl o tym, żebyś wskrzeszony

Na prawicy był stawiony!"

Tak jest: wierzę w zmartwychwstanie!

Juz w wesolym jestem stanie,

125 Ani się z tego juz smuç,

Ze wkrótce w proch się obrócę -

Z prochu wzięty, w proch wrócony,

I z prochu będę wskrzeszony.

${ }_{17}$ Nawiązanic do Biblii (w. 90-1(14), Ap 20). 13-14: ..... i śmicré i picklo dali umarte swe, którzy w nich byli, i sądzono każdego wedle uczynków jego. A śmicré i pickło wrzucono w jezioro ogniste..." (tl. J. Whijek).

Is Nawiązanic do Biblii, Rdz 2, 7: ..Utworzyl tedy Pan Bóg czlowicka z mulu ziemic, i natchnąl w oblicze jego dech żywota; i stal się czlowick w duszę żywiącą" (tl. J. Whijck). 